\title{
Postprandial dysmetabolism: assessment and treatment
}

\author{
Niki Katsiki ${ }^{1}$, Genovefa Kolovou ${ }^{2}$ \\ ${ }^{1}$ Second Propedeutic Department of Internal Medicine, Medical School, Aristotle University of Thessaloniki, Hippocration \\ Hospital, Thessaloniki, Greece; ${ }^{2}$ Cardiology Departmentand Molecular Immunology Laboratory, Onassis Cardiac Surgery \\ Center Athens, Greece
}

We read with interest the Pappas et al review on postprandial dysmetabolism. ${ }^{1}$ The authors describe evidence linking elevated levels of postprandial glucose and triglycerides (TGs) with cardiovascular (CV) morbidity and mortality as well as with polycystic ovary syndrome (PCOS), non-alcoholic fatty liver disease (NAFLD) and lack of hepatic receptors such as low density lipoprotein receptor (LDLR). ${ }^{1}$ Specifically, it was reported that subjects with familial hypercholesterolemia have exaggerated and prolonged response to fatty meal loading. ${ }^{2}$ The authors also discuss methods for screening and diagnosis of postprandial dysmetabolism as well as therapeutic options including lifestyle modifications, antidiabetic and hypolipidemic drugs.

The lack of a widely approved standardized protocol for the assessment of postprandial lipemia (PPL) impedes the early diagnosis and adequate treatment of this metabolic disorder. ${ }^{3}$ In this context, a previous meta-analysis proposeda $4 \mathrm{~h}$ time-point following an oral fat test meal containing 70-79 $\mathrm{g}$ of fat as the most representative method to measure PPL. ${ }^{4}$ Pappas et al. ${ }^{1}$ mention the cut-off point of $175 \mathrm{mg} /$ $\mathrm{dl}$ for non-fasting TGs as suggested by White et $\mathrm{al}^{5}$

Address for correspondence:

Genovefa D. Kolovou, MD, PhD, FESC, SFASA, FRSPH,

Director, Cardiology Department, Lipid Disorders Clinic,

Onassis Cardiac Surgery Center, 356 Sygrou Ave, 17674

Athens, Greece; Tel.: +30 210 9493520, Fax: +30 2109493336 ,

E-mail: genovefa@kolovou.com

Received: 20-11-2016, Accepted: 26-11-2016 in a sub-population of the Women's Health Study. An expert panel statement had earlier discussed the clinical implications and assessment of PPL proposing as optimal non-fasting TGs $<180 \mathrm{mg} / \mathrm{dl}$ (2 $\mathrm{mmol} / \mathrm{l})$ and desirable postprandial TGs $\leq 220 \mathrm{mg} /$ $\mathrm{dl}(2.5 \mathrm{mmol} / \mathrm{l})$ at any time following a fat tolerance test (given after $8 \mathrm{~h}$ of fasting and consisting of $75 \mathrm{~g}$ fat, $25 \mathrm{~g}$ carbohydrates and $10 \mathrm{~g}$ protein). ${ }^{6}$ The same expert panel recommended that a fat tolerance test should be performed in individuals with non-fasting TGs $89-180 \mathrm{md} / \mathrm{dl}$ (1-2 mmol/l).

Antidiabetic and hypolipidemic drugs have been reported to improve postprandial dysmetabolism as mentioned by Pappas et al. ${ }^{1}$ Statins and insulinsensitizer drugs (i.e. metformin and pioglitazone) were also shown to beneficially affect metabolic and menstrual abnormalities in PCOS. ${ }^{7}$ Moreover, it was found that gut peptides such as glucagon-like peptide-1 (GLP-1) and GLP-2 could be involved in homeostasis of PPL. Thus, the GLP-1 receptor agonists (GLP-1 RA) may be able to improve metabolic features in PCOS women but further research is needed in this field. ${ }^{8}$ With regard to NAFLD, statins and antidiabetic drugs [e.g. pioglitazone, dipeptidyl peptidase-4 (DPP-4) inhibitors, GLP-1 RA and sodium-glucose co-transporter 2 (SGLT2) inhibitors] are also likely to improve biochemical and/or histological features of NAFLD and its advanced form i.e. non-alcoholic steatohepatitis (NASH) ${ }^{9-13}$ Overall, combination therapy with both antidiabetic and hypolipidemic drugs may be a useful therapeutic tool for patients with postprandial dysmetabolism and PCOS or NAFLD. ${ }^{14-16}$ 
Nevertheless, further investigations are required to firmly establish such associations.

\section{DECLARATION OF INTEREST}

This letter was written independently; no company or institution supported it financially. NK has given talks, attended conferences and participated in trials sponsored by Amgen, Angelini, AstraZeneca, Boehringer Ingelheim, MSD, Novartis, Novo Nordisk and Sanofi-Aventis. GK has given talks, attended conferences and participated in trials sponsored by Amgen, Angelini, MSD, Lilly, Vianex and SanofiAventis.

\section{REFERENCES}

1. Pappas C, Kandaraki EA, Tsirona S, Kountouras D, Kassi G, Diamanti-Kandarakis E, 2016 Postprandial dysmetabolism: Too early or too late? Hormones (Athens) 15: 321-344.

2. Kolovou GD, Kostakou PM, Anagnostopoulou KK, 2011 Familial hypercholesterolemia and triglyceride metabolism. Int J Cardiol 147: 349-358.

3. Kolovou GD, Mikhailidis DP, Kovar J, et al, 2011 Assessment and clinical relevance of non-fasting and postprandial triglycerides: an expert panel statement. Curr Vasc Pharmacol 9: 258-270.

4. Mihas C, Kolovou GD, Mikhailidis DP, et al, 2011 Diagnostic value of postprandial triglyceride testing in healthy subjects: a meta-analysis. Curr Vasc Pharmacol 9: 271-280.

5. White KT, Moorthy MV, Akinkuolie AO, et al, 2015 Identifying an optimal cutpoint for the diagnosis of hypertriglyceridemia in the nonfasting state. Clin Chem 61: 1156-1163.

6. Kolovou GD, Mikhailidis DP, Nordestgaard BG, Bilianou H, Panotopoulos G, 2011 Definition of postprandial lipaemia. Curr Vasc Pharmacol 9: 292-301.

7. Spritzer PM, Motta AB, Sir-Petermann T, DiamantiKandarakis E, 2015 Novel strategies in the management of polycystic ovary syndrome. Minerva Endocrinol 40: 195-212.

8. Tzotzas T, Karras SN, Katsiki N, 2016 Glucagon-like peptide-1 (GLP-1) receptor agonists in the treatment of obese women with polycystic ovary syndrome. Curr Vasc Pharmacol Dec 21. [Epub ahead of print].

9. Athyros VG, Katsiki N, Karagiannis A, Mikhailidis DP, 2013 Statins and non-alcoholic fatty liver disease: a bright future? Expert Opin Investig Drugs 22: 1089-1093.

10. Athyros VG, Katsiki N, Karagiannis A, 2016 Editorial: can glucagon like peptide 1 (GLP1) agonists or sodiumglucose co-transporter 2 (SGLT2) inhibitors ameliorate non-alcoholic steatohepatitis in people with or without diabetes? Curr Vasc Pharmacol 14: 494-497.

11. Musso G, Cassader M, Rosina F, Gambino R, 2012 Impact of current treatments on liver disease, glucose metabolism and cardiovascular risk in non-alcoholic fatty liver disease (NAFLD): a systematic review and meta-analysis of randomized trials. Diabetologia 55: 885-904.

12. Blaslov K, Bulum T, Zibar K, Duvnjak L, 2014 Incretin based therapies: a novel treatment approach for nonalcoholic fatty liver disease. World J Gastroenterol 20: 7356-7365.

13. Katsiki N, Mikhailidis DP, Mantzoros CS, 2016 Nonalcoholic fatty liver disease and dyslipidemia: An update. Metabolism 65: 1109-1123.

14. Athyros VG, Katsiki N, Mikhailidis DP, 2016 Editorial: resolution of non-alcoholic-steatohepatitis. More than one drug needed? Curr Vasc Pharmacol 14: 313-315.

15. Sun J, Yuan Y, Cai R, et al, 2015 An investigation into the therapeutic effects of statins with metformin on polycystic ovary syndrome: a meta-analysis of randomised controlled trials. BMJ Open 5: e007280.

16. Katsiki N, Athyros VG, Mikhailidis DP, 2016 Nonalcoholic fatty liver disease in patients with type 2 diabetes mellitus: effects of statins and antidiabetic drugs. J Diabetes Complications. [Epub ahead of print]. 